\title{
Inflation Targeting Regimes, Institutional Flexibility and Growth Performance: A Keynesian/Kaldorian Perspective in a Dynamic Panel Analysis"
}

\author{
Marcos Rocha ${ }^{* *}$ \\ José Luis da Costa*
}

\begin{abstract}
The objective of this paper is to investigate if Inflation Targeting Regime (hereafter ITR) institutional design has any relationship with growth performance of ITR countries. For this intent, it is initially presented a modified Kaldorian cumulative causation model in order to discuss the effects of changes in the monetary policy rules over the time path of real output, nominal interest rates and inflation. The model has as its main results that a balanced growth path requires that central banks set a long-run target for inflation that is flexible and adjustable to the conditions prevailing in the word's economy. The theoretical model to be presented here shows that flexibility in the definition of the target rate of inflation is an important issue for a balanced growth in the long-run. This result supports the main empirical hypothesis of this paper according to which the level of institutional flexibility of an ITR has a positive relationship with output performance of the ITR countries In order to test the hypothesis, it is estimated a dynamic panel in which output growth rates are related to some proxy variables that represents the level of ITR institutional flexibility. The empirical results support the hypothesis that institutional flexibility of ITR and economic growth have a relationship.
\end{abstract}

Key-Words: Economic Growth, Monetary Policy and Inflation Targeting.

JEL: C23, F31, F33

Resumo: O objetivo deste artigo é investigar se o arranjo institucional do Regime de Metas de Inflação (RMI) tem alguma relação com o desempenho de crescimento dos países que adotaram RMI. Para isto, é inicialmente apresentado um modelo Kaldoriano de causação cumulativa, de forma a discutir os efeitos de mudanças nas regras de política monetária sobre a trajetória no tempo do produto, taxa de juros e inflação. O modelo tem como seus principais resultados que uma trajetória de crescimento do produto sustentada requer que os bancos centrais definam uma meta de longo-prazo para a inflação que é flexível e ajustável às condições correntes da economia mundial. Este resultado apóia a hipótese central dos experimentos empíricos do trabalho, qual seja, de que o nível de flexibilidade institucional do RMI tem uma relação positiva com a performance de produto dos países que adotam RMI. Para fazer tal inferência, foi estimado um painel dinâmico no qual as taxas de crescimento do produto são relacionadas a algumas variáveis proxies de flexibilidade do RMI. Os resultados empíricos em seu conjunto apontam uma relação entre flexibilidade institucional do RMI e crescimento econômico.

Palavras-chave: Crescimento Econômico, Política Monetária, Metas de Inflação.

JEL: C23, F31, F33

\section{Endereço para Correspondência: Aos cuidados de Marcos Rocha \\ Rua da União, 299 - Vila Mariana - São Paulo - SP \\ Email: marcosrocha@gvmail.br Telefone: (41) 99057520}

\section{Área 3 - Macroeconomia, Economia Monetária e Finanças}

\author{
Rubens Penha Cysne (FGV-RJ) \\ Jennifer Hermann (UFRJ) \\ Roberto Ellery (UnB)
}

\footnotetext{
\#The authors recognize de valuable comments of Gary Dymsky, Phillip Arestis, Malcon Sawyer, Paul Davidson, Luiz Fernando de Paula and Márcio Holland.

** Graduate Student of Economics at Fundação Getúlio Vargas, São Paulo. E-mail: sir.mrocha@gmail.com.

* Associate Professor of Economics at Universidade Federal do Paraná (UFPR) and Researcher of the Scientific National Council (CNPq). E-mail: joreiro@ufpr.br. Web-page: www.joseluisoreiro.ecn.br. The aut
} 


\title{
Inflation Targeting Regimes, Institutional Flexibility and Growth Performance: A Keynesian/Kaldorian Perspective in a Dynamic Panel Analysis
}

\begin{abstract}
The objective of this paper is to investigate if Inflation Targeting Regime (hereafter ITR) institutional design has any relationship with growth performance of ITR countries. For this intent, it is initially presented a modified Kaldorian cumulative causation model in order to discuss the effects of changes in the monetary policy rules over the time path of real output, nominal interest rates and inflation. The model has as its main results that a balanced growth path requires that central banks set a long-run target for inflation that is flexible and adjustable to the conditions prevailing in the word's economy. The theoretical model to be presented here shows that flexibility in the definition of the target rate of inflation is an important issue for a balanced growth in the long-run. This result supports the main empirical hypothesis of this paper according to which the level of institutional flexibility of an ITR has a positive relationship with output performance of the ITR countries In order to test the hypothesis, it is estimated a dynamic panel in which output growth rates are related to some proxy variables that represents the level of ITR institutional flexibility. The empirical results support the hypothesis that institutional flexibility of ITR and economic growth have a relationship.
\end{abstract}

Key-Words: Economic Growth, Monetary Policy and Inflation Targeting.

JEL: C23, F31, F33

Resumo: O objetivo deste artigo é investigar se o arranjo institucional do Regime de Metas de Inflação (RMI) tem alguma relação com o desempenho de crescimento dos países que adotaram RMI. Para isto, é inicialmente apresentado um modelo Kaldoriano de causação cumulativa, de forma a discutir os efeitos de mudanças nas regras de política monetária sobre a trajetória no tempo do produto, taxa de juros e inflação. $\mathrm{O}$ modelo tem como seus principais resultados que uma trajetória de crescimento do produto sustentada requer que os bancos centrais definam uma meta de longo-prazo para a inflação que é flexível e ajustável às condições correntes da economia mundial. Este resultado apóia a hipótese central dos experimentos empíricos do trabalho, qual seja, de que o nível de flexibilidade institucional do RMI tem uma relação positiva com a performance de produto dos países que adotam RMI. Para fazer tal inferência, foi estimado um painel dinâmico no qual as taxas de crescimento do produto são relacionadas a algumas variáveis proxies de flexibilidade do RMI. Os resultados empíricos em seu conjunto apontam uma relação entre flexibilidade institucional do RMI e crescimento econômico.

Palavras-chave: Crescimento Econômico, Política Monetária, Metas de Inflação.

JEL: C23, F31, F33 


\section{Introduction}

The new consensus on macroeconomics establishes that a low and stable inflation rate is of fundamental importance for long-run growth (Arestis and Sawyer, 2006, p.5) and that there is no long-run trade-off between inflation and unemployment (Fontana e Palacio-Vera, 2007). Another element of the new consensus is that discretion in the conduction of monetary policy should be limited in order to guarantee a low and stable rate of inflation and to minimize the variability of output growth. Although the adoption of a simple k-per cent rule as suggested by Friedman (1968) may not be an optimal monetary policy in an uncertain environment ${ }^{1}$, the mainstream literature on monetary policy argues that central banks discretion must be institutionally restricted in order to reduce the problem of inflation-bias ${ }^{2}$ that arise when monetary policy was conducted with discretion. A “constrained discretion”, to use Bernanke's famous terminology, can be attained by the adoption of a monetary policy framework where central bank's actions and goals are transparent and accountable.

Transparence and discipline in the operation of monetary policy required a nominal anchor for monetary policy. In the 90's, a growing number of countries has adopted an Inflation Targeting Regime (hereafter, ITR). The ITR is a framework for monetary policy where i) a numerical target or range for inflation rate is defined as the most important or the sole goal of monetary policy; ii) the target rate of inflation is supposed to be achieved by means of appropriate changes in nominal short-term interest-rates set by Central Bank (hereafter CB); iii) monetary policy is conducted by an independent CB (Sawyer, 2006). The widespread use of ITR had taken place partially due to the failure of the other nominal anchor strategies to control the rate of inflation. Alternative nominal anchors are the exchange rate targeting and the monetary targeting. In the monetary targeting case, the problem was due to the fact that the empirical relation between inflation and monetary aggregates became very tenuous in the 70's, maybe as a direct result of financial innovations that occurred from that time on, which produce a remarkable instability in the velocity circulation of money $^{3}$. The exchange-rate target was finally abandoned in the 90's after the emergence of a great number of successive exchange-rate crisis in several countries (Argentina, Brazil, Russia, East Asia Countries) as a result of the perverse combination between a fixed-exchange rate regime with liberalized capital accounts.

So, the new consensus on macroeconomics establishes that ITR is a good institutional framework to guarantee low rates of inflation and to minimize output fluctuations ${ }^{4}$. The reason is that ITR is supposed to produce a "constrained discretion" that combines flexibility and credibility in a ideal way, permitting the $\mathrm{CB}$ to react to unforeseen recessions by means of the appropriate change in short-term interest rates in order to minimize output fluctuations around the long-run trend of output; it also reduces the degrees of freedom of CB to produce "inflation surprises" in order to explore the short-run trade-off between inflation and unemployment.

\footnotetext{
${ }^{1}$ See Walsh (2001, pp. 467-472).

${ }^{2}$ There is an extensive literature dealing with the time inconsistency problem, most of which related to Kydland and Prescott (1977) seminal work. The authors show that the central banks' inability in compromise to a low inflation policy could lead to excessive inflation, even in the absence of a long run trade-off between output and inflation. If the expected inflation is low and, therefore, the marginal social cost of increasing inflation rate is low, the policy-makers should determine expansionary policies as a means to elevate temporarily the output level above its normal equilibrium level (market imperfections and other factors could make the potential output to be less than what is socially desirable, justifying that motivation). The general knowledge of this policy-makers' incentive, or even the simple existence of this possibility for the central banks when there is no clear compromise with low inflation rates leads to the increase of inflation expectations; this result is the inflation bias, which cause is inter-temporal or dynamic inconsistency. After all, the discretionary policies results only in more inflation and no output increase.

${ }^{3}$ As Carlin and Soskice (2006) pointed out, in United Kingdom was common that, when the monetary authorities tried to control a particular monetary aggregate, there was a sequential response from financial system which generates close substitutes to money, hence getting rid of the target established. Changes in money demand (or the instability of money transactions velocity) undermine the link between monetary growth target and inflation. These problems mentioned had lead to the end of this practice in USA, Canada and UK.

${ }^{4}$ About this consensus, see Woodford (2003).
} 
This optimism about the virtues of ITR is not shared by post-keynesian and other heterodox economists. For the majority of post-Keynesian economists, ITR can not be considered an appropriate framework for monetary policy since i) it is based on the axiom of money neutrality ${ }^{5}$ since it assumes the existence of a natural rate of unemployment, determined by the supply side of the economy and largely independent of monetary policy (Arestis and Sawyer, 2005; Palley, 2006); and ii) it assumes that inflation is largely the result of excess aggregate demand, that is, a situation where aggregate demand is bigger that equilibrium output determined by the supply side of the economy. Post Keynesian economics, on the other hand, assumes that money is non-neutral in the short and in the long-run, what means that there is no long-run equilibrium for the economy that is independent of monetary policy (Carvalho, 1992, p. 38). As a direct corollary of long-run nonneutrality of money, there is no sense in defining price-stability as the most important or the sole goal of monetary policy as it is required by an ITR. Besides that, post Keynesian economists adopt the so-called structuralist view of inflation, according to which inflation is the result of a conflict between workers and capitalists over the distribution of income between wages and profits (Arestis and Sawyer, 2005). In this framework, if the target wage of workers and the target mark-up of firms are exogenously determined, then inflation rate is completely insensitive to changes in the shortterm interest rate by the CB (Palley, 1996, p.182).

More recently, some post-keynesian economists begin to reconsider the theoretical compatibility between ITR and post-keynesian economics. One example is Palley (2006). According to him, ITR could make sense for post-keynesian economics if one postulates the existence of a backward bending long-run Phillips curve. The logic of his reasoning is based on the idea that for very low levels of inflation, workers have some kind of "money illusion", what creates a negative relation between inflation and unemployment over a limited range of the long-run Phillips curve. For this range of the long-run Phillips curve, monetary policy should be conducted in order to achieve that rate of inflation that minimizes the unemployment rate. In order words, monetary policy should be guided by M.U.R.I (minimum unemployment rate of inflation). In this setting, a ITR is a desirable framework for achieving the lowest level of unemployment compatible with a stable rate of inflation (Palley, 2006, p.248-249).

Another example of the issue at hand is Setterfield (2005). This author elaborate a macroeconomic model with post-keynesian features, where output is demand determined, inflation results from a distributive conflict between workers and capitalists and Central Bank defines an explicit target for the rate of inflation as well as a target for real output. In this framework it is possible to show that the long-run equilibrium of the system is stable what demonstrates the potential desirability of an ITR for the stability of an economy with post-keynesian features.

Despite the growing consensus about the desirability of ITR, the empirical literature about the success of ITR in fighting inflation is still controversial. In a review of recent empirical literature about the relation between interest rates and inflation, Arestis and Sawyer (2006) found that the macroeconometric models for the Euro zone (the ECB area-wide model) shown a small effect of interest rate changes over the rate of inflation. More precisely, they found that a one per cent increase in the short term interest rate in the Euro zone for two years produced a peak reduction of 0.16 per centage point in the second year, which is reduced to only 0.08 per centage reduction in inflation rate in year four and reversed to the benchmark level of the simulation in year five. However, the impact of interest rate changes over investment expenditure is substantial. They report that a one per cent increase in short-term interest rates for two years reduced investment expenditure in 0.39 per centage points after five years. This evidence suggest that interest rate variations can have long-lasting effects over investment and the stock of capital, showing the longrun non-neutrality of monetary policy (Arestis and Sawyer, 2006, p.16).

Given the notorious effects of interest rate changes over output and investment, an important issue of the debate about ITR desirability refers to the institutional design of the system. In other words, is there any alternative institutional design for a ITR that could reduce the costs associated to

\footnotetext{
${ }^{5}$ About the importance of the axiom of money neutrality for mainstream economics see Davidson (2002, p.41) and Carvalho (1992, p.32). .
} 
interest rate changes and/or minimize the required changes in interest rates for the accomplishment of the inflation target? More specifically, can we define different degrees of institutional flexibility of an ITR, so that a more flexible ITR could, in principle, be compatible with a better performance of output growth than a less flexible ITR?

In this paper it will be defined ITR institutional flexibility as the degree of possibilities allowed by the ITR design for the central banks adjust itself to worlds' economy conditions; for example, by changing its target in face to adverse shocks. In sum, it's the space to practice the "constrained discretion" that it is pointed out by ITR advocates as the regime main advantage over other monetary regimes.

As it will be developed in this paper, the ITR in a country could have many institutional designs: its institutional format is crucial to guarantee the targets accomplishment and credibility building. In the moment that ITR is adopted, the policy-makers have a wide range of institutional operation issues to determine: the use of core inflation or headline inflation to guide the targets; to establish a point inflation target or bands of many wide ranges; to announce a time horizon of one year or a longer period of target convergence, etc. Each of these options can give to the monetary institution a specific fashion: it can be "tight", in a sense that the IT is build with strong emphasis toward target success despite any operational cost of convergences; or the IT can be more "flexible", when the regime tends to take into account the costs and time horizons needed to get the targets' hit. These opposite sides - tight and flexible regimes - are strongly related to, on one hand, credibility, a fundamental issue for tight regimes or ITR in consolidation, which is more commonly adopted by countries looking for a decreasing inflation rates path; on the other hand, there is the preoccupation about the interest and exchange rates volatility associated to tight ITRs. On the subsequent sections of this paper will become clearer which institutional frameworks are flexible and which is tight and what are the consequences of these regime arrangements to countries' growth performance.

The main goal of this paper is to investigate if ITR institutional design has a relationship with growth performance of ITR countries. Hence, the work deal with macroeconomic policies analysis in a wider sense - more than just focus on price stability, the economic growth has its special attention. The discussion lies on the potential role of the institutional design of ITR over growth performance of the countries. For this intent, is presented a modified Kaldorian cumulative causation model in order to discuss the effects of changes in the monetary policy rules over the time path of real output, nominal interest rates and inflation. The model has as its main results that a balanced growth path requires that central banks set a long-run target for inflation that is flexible and adjustable to the conditions prevailing in the word's economy. The theoretical model to be presented here shows that flexibility in the definition of the target rate of inflation is an important issue for a balanced growth in the long-run. This result supports the main empirical hypothesis of this paper according to which the level of institutional flexibility of an ITR has a positive relationship with output performance of the ITR countries, since it gives more degrees of freedom to monetary authorities to adjust itself to adverse shocks than those countries with tight ITR. In order to do that, we will estimate a dynamic panel in which output growth rates are related to some proxy variables that represents the level of ITR institutional flexibility.

Following this introduction, the section 2 details the operation of IT regimes and introduces some evidences of the international experience. The section 3 details the theoretical background that guide the dynamic panel function used in the econometric exercises. The section 4 explores the empirical results. The section 5 ends the paper with some final comments.

\section{The inflation targeting institutional arrangements.}

This section details some operational aspects related to ITR adoption ${ }^{6}$. The ITR framework must be designed for the monetary policy conduction to be oriented towards the inflation target; at

\footnotetext{
${ }^{6}$ A quick evaluation of the international ITR institutional framework designs can be accessed in Rocha and Oreiro (2008).
} 
the same time, however, it should be taken into account by central bankers the limits that arise for such a task. The inflation rate is not a variable under full control of the Central Bank. Furthermore, central banks face social costs in terms of output growth - which can be long lasting costs if money is not neutral - when designing monetary policies.

The institutional design of an ITR is defined by four elements: the time horizon of IT, the adoption of a point or a band for the target, the number value of the target and the specific measure of inflation target. The combination of all these features defines the level of institutional flexibility of a ITR. Although a numerical evaluation of the level of flexibility of an ITR is possible, no such an attempt will be made in this paper. Now we will discuss each of these elements of the institutional design of an ITR in some detail.

The time horizon of ITs. The IT time horizon is the period expected by monetary authorities that the monetary policies have effect in adjusting the inflation rate to its target. The inflation rates do not return immediately to the target settled because there are several nominal frictions (such as wage contracts) that make inflation persistent. Besides, the monetary policy act in lags, as Friedman (1969) pointed out emphatically when suggested precautions in the use of money instruments. As ITR gives priority in anchoring the inflation expectations, the policy-makers looks for enhanced transparency in their policies by communicating to the public the time horizon settled. The choice of the appropriate period of target convergence involves a trade-off between the cost in terms of output and interest rates volatility in one hand and the benefits of keeping the inflation under control on the other. As underlined by Colleti et al (2006), the length of convergence that it takes to reach the target varies widely, depending upon the intensity and nature of the shocks over the economy. When there is a price level acceleration detonated by a persistent shock, such as asset bubbles for example, it would be necessary an expansion of the inflation targeting time horizon as a means to accommodate, in a stable way, the potential unstable effects of the shock.

A short convergence period is associated to big changes in the interest rates as a way to get quickly the inflation rate into the target. This means that a short convergence period defines a tight ITR. The monetary policy affects the economic variables, particularly the inflation rate, in lags that are typically estimated to be two years, according to Mishkin (2001). For this author, smaller time horizons, as has been adopted by some ITR arrangements, can bring about three problems on the regime conduction. Such small horizons tend to be associated to a frequent loss of the target. The second problem is related to shorter horizons is the instrumental instability: the policy instruments are called into action excessively in this short period of convergence. The results in this case is the excessive volatility of the interest rates, since the lagged effects on the economy resulted from interest rates volatility should be corrected by subsequent deviations of the interest rates in a opposite direction. A third issue pointed out by Mishkin is that a short convergence horizon shows to the public that the CB does not give proper weight to output gaps in its social loss function.

A larger convergence period is associated with a slower change in the interest rates, which tends to result in smaller volatility of real output; however, this arrangement could make the inflation deviations from its target to be more persistent. Therefore, it can be said that there is an optimum time horizon for target convergence that would balance these two opposite scenarios. Each shock has its own optimum time horizon, with each shock bringing a different trade-off between target hit and inflation and output volatility.

On determining the optimum time horizon for IT, it is necessary a quantitative measure of the losses derived in terms of the output and inflation volatilities associated to shorter time horizon on one hand and the degree of credibility lost when is settled a wider horizon policy.

The adoption of a point or a band for the target. The central bank can choose between defining a point target or an interval around a medium point. The choice of an interval for the target put to the CB a trade-off related to the width of the band. On one hand, when central banks adopts a more narrow band, it communicates to the public a stronger compromise in reaching the target than it would a wider band; so, more credibility is related to narrower bands. On the other hand, target bands that are too narrow reduce considerably the ability of the monetary authority to answer to 
unexpected exogenous shocks. Moreover, the damage to central bank image resulted of the loss of the target is considerably larger than that of losing a point target.

Table 1 - Central Bank Targets, Inflation Measures and Time Horizons

\begin{tabular}{|c|c|c|}
\hline Country & Inflation Index & Compromise Horizon \\
\hline Austrália & Headline Inflation & Medium-Term \\
\hline Brazil & Headline Inflation & 1 year \\
\hline Canadá & Headline Inflation & 5 years \\
\hline Chile & Headline and Core Inflation & Medium-Term \\
\hline Colômbia & Headline Inflation & Long-Run \\
\hline Czech Republic & Headline Inflation & Eurozone Access \\
\hline Hungary & Headline Inflation & Medium-Term \\
\hline Iceland & Headline Inflation & Medium-Term \\
\hline Indonésia & Headline Inflation & Medium-Term \\
\hline Israel & Headline Inflation & Non Specified \\
\hline Korea & Headline Inflation & 3 years \\
\hline Mexicoo & Headline Inflation & Non Specified \\
\hline New Zealand & Headline Inflation & Medium-Term \\
\hline Norway & Core Inflation & Non Specified \\
\hline Peru & Headline Inflation & Non Specified \\
\hline Phillipines & Headline Inflation & Non Specified \\
\hline Poland & Headline Inflation & Medium-Term \\
\hline Romênia & Headline Inflation & 2 years \\
\hline Eslovaq & Headline Inflation & 3 years \\
\hline South África & CPI excluding mortgage interest & Non Specified \\
\hline Sweden & Headline Inflation & Non Specified \\
\hline Thailand & Core Inflation & Non Specified \\
\hline Turkey & Headline Inflation & 3 years \\
\hline United Kingdom & Headline Inflation & 1 year \\
\hline
\end{tabular}

The number value of the target. Once a ITR is built, a main issue is the definition of the long run inflation target. For Mishkin (2001), evaluations about long run targets need as first step a clear definition of what is price stability, and quotes the famous Greenspan's definition that the price stability is that one sufficiently low so that the individuals of the economy don't need to take it into account in their daily economic decisions. According to this definition, any inflation rate between 0 and 3 percent can be satisfactory for developed countries, although some economist as Feldstein (1997) and Poole (1999) support a long run inflation of zero percent, whose virtue would be the appeal of a "magic number", the zero, to the agents' expectations. The international experience, however, as it can be noted in Bernanke et al (1999), suggests that there is no evidence that the maintenance of the inflation target above zero (but not too much than this), for an extensive period, did bring instability to the public's expectations or decline of central banks credibility. Besides, Akerlof et al (1996) argues that to define the inflation at so low levels produce an inefficiency that results in an increase of the natural rate of unemployment. The authors say that the downward rigidity of nominal wages creates an economy's context where too low inflation rates, as zero for instance, turns impossible an effective adjustment of nominal wages down in response to declining demand for work in some industries or areas, which results in the increase of unemployment and in the hindering of the labor allocation between declining industrial sector and those in expansion ${ }^{7}$.

\footnotetext{
${ }^{7}$ Mishkin (2001), arguing against the zero inflation target hypothesis, says that such a goal for central banks would probably lead the economies to experience deflationary episodes potentially quite dangerous, once it promotes financial instability and could make monetary policy more difficult, if the short-run interest rates hit the zero floor as result. Hence, the logic against de inflation zero targeting is that a positive inflation rate provides safety against deflationary episodes. Mishkin (2001) still underline an additional reason so that central banks establishes above zero targets:
} 
The inflation measure to the target. The inflation measure used to guide the IT is one of the first steps in designing the regime. If the monetary authority main goal is to maximize the transparency of monetary policy operation, the price index, as suggests Bernanke et al (1999), should be one of which people are already familiarized and that it is wide and accurate. If monetary authority searches for more flexibility, the price index could exclude some kind of price changes that supposedly does not affect the inflation trend - the so called core inflation, which excludes some prices associated to interest rates or to temporary price movements of volatile nature.

The headline price index has been the main choice in inflation targeting, and just a few countries still adopts core inflations in their regimes (see Table 1). The main reason for that can be that the monetary authority does not want the public to take the impression that the central bank chooses the index that better guarantees more favorable results. In other words, the priority to the creditability over publics' expectations with the use of a headline index has been more important to $\mathrm{CB}$ than the potential flexibility offered by core inflation targeting. Although the core price index is less volatile for most of the IT countries, in many of them the core index was designed in such a way that it has little difference (or not great difference) in terms of volatility with the headline index time series.

In Brazil, the core inflation index is not used as guide to targets. One of the reasons, as pointed out by Minella et al (2002), is that in some occasions during the 1970's and 1980's, the government had excluded some items from the price index with ad hoc motivations as an artifice to reduce the official inflation rates; sometimes, even the index calculation was changed to this end. The final result is that the public in Brazil is quite reluctant in accepting an index that excludes some items, in face of those last experiences.

\section{Growth and monetary non-neutralities: a post-keynesian approach.}

Neoclassical growth models take for granted that the ultimate limit to long-run growth is the supply of factors of production (cf. Solow, 1957). Aggregate demand is relevant only to determine the degree of productive capacity in the short-run, but has no lasting impact over the growth rate of productive capacity. In the long-run, Say’s Law is valid, that is, supply determines demand.

However, supply of factors of production is not really independent of demand. The relation between the supply of production factors and aggregate demand was analyzed by Kaldor (1988), giving a new stimulus to the so-called demand-led growth theory ${ }^{8}$. The starting point of the demand-led growth models is that means of production used in a capitalist economy are themselves goods produced within the system. If that is so, the "supply" of means of production should never be considered as a datum independent of the demand for then. In this framework, the fundamental economic problem is not the allocation of a given quantity of resources over the possible alternatives; but the determination of the rate of growth of these resources. In the words of Setterfield:

"The use of produced means of production implies that the 'scarcity of resources' in processing activities cannot be thought of as being independent of the level of activity in the

otherwise, they can be viewed by the public as obsessed with inflation control to the expenses of the equally necessary output stability, losing then the legitimacy avail of the society.

${ }^{8}$ The importance of aggregate demand for long-run growth was emphasized by other Keynesian authors before Kaldor. In the growth model of Joan Robinson (1962), for example, the growth rate of capital stock is determined by the interplay between propensity to invest of capitalists (determined by their animal spirits) and the propensity to save out of profits. An increase in the propensity to save out of profits will produce a reduction in the desired rate of accumulation, showing the fundamental importance of aggregate demand for long-run growth. However, it remains the idea that the availability if means of production sets an upper limit for long-run growth. In fact, the growth rate of the labor force is considered an exogenous variable in the system and can set an upper limit to economic growth since the economy could not grow indefinitely at a rate bigger than the one allowed by the expansion of the labor force (adjusted by technical progress) In 1988 article, Kaldor argued that, in the long-run, the growth rate of labor force is not independent of demand, but adjusts itself to the growth of demand for labor. 
economy. What is chiefly important in processing activities is the dynamic propensity of the economy to create resources (that is, to deepen and/or widen its stock of capital) rather than the static problem of resource allocation" (1997, p.50).

Kaldor's ideas about demand-led growth have been presented in formal models of cumulative causation where the rate of growth of output is determined by the growth rate of exports, which is determined by the growth rate of labor productivity (considering a fixed exchange-rate regime) induced by the growth rate of real output ${ }^{9}$. In this setting, it is possible the construction of dynamic models where initial conditions largely determine the long-run growth rate $^{10}$.

Up to now, however, no effort has been done in order to incorporate to these dynamic models some important aspects of open-economy macroeconomics as, for example, the openness of capital account and the existence of a floating exchange-rate regime. Besides that, Kaldorian models of cumulative causation ignore completely the effects of monetary policy over long-run growth, what is a surprising feature, given the obvious Keynesian pedigree of this class of growth models.

The model presented here is an extension of the Kaldorian model of cumulative causation developed by Setterfield (1997). It is well known that the standard model of cumulative causation has four dynamic equations: a first equation relating the growth rate of labor productivity with the growth rate of real output (the so-called Kaldor-Verdoorn Law), a second equation presenting the rate of inflation as the difference between the rate of increase in nominal wages and the growth rate of labor productivity, a third equation showing the growth rate of exports as a function of the evolution of price-competitiveness of exports and the growth rate of world's income and a forth and last equation showing the growth rate of real output as a function of the growth rate of exports.

In the model develop in this paper, there are some modifications in the basic structure of the standard Kaldorian cumulative causation model. First of all, as suggested by Palley (2002), it is added two new equations to the standard model with the purpose to analyze the dynamics of the productive capacity of the economy. In fact, standard models of cumulative causation say nothing about the "supply side" of the economy, that is, about the evolution of productive capacity through time. This omission will be solved by means of adding a dynamic equation relating the growth rate of productive capacity with the investment rate, in a similar fashion of what was done by Domar (1936). The second equation to be introduced is a investment function in which investment rate at time $t$ will be supposed as being a function of the growth rate of real output in time $t-1$ - according with the so-called accelerator model of investment behavior - and of the real interest rate of time $t$ 1 .

In second place, it will be supposed that the rate of change of nominal wages is not uniform in all over the world economy (cf. Setterfield, 1997, p.55), but is country-specific. In this setting, it is assumed that domestic Labor Unions can manage to fix the rate of change in nominal wages at a rate equal to inflation rate of the last period plus all the productivity gains occurred in the last period.

In third place, it is assumed an economy that operates under a floating exchange-rate regime in a setting of restricted (imperfect) capital mobility due to the presence of some form of capital controls. In this framework, the rate of change of nominal exchange-rate is supposed to be a linear function of the difference between the domestic nominal interest rate and the international nominal interest rate adjusted by the country-risk premium. Because of that, the interest rate differential will have an impact over the domestic rate of inflation (by means of exchange-rate variations) and overt

\footnotetext{
${ }^{9}$ Some empirical evidences about the validity of these classes of models must be obtained in Ledesma and Thirwall (2002).

${ }^{10}$ See Dixon and Thirwall (1975) and Setterfield (1997).
} 
the price-competitiveness of exports, opening a channel by which monetary policy can have an influence over long-run growth rate.

Finally, it is supposed that monetary policy is conducted under the institutional framework of an Inflation Targeting Regime, and the Central Banks sets nominal interest rates at each period based in a version of the so-called "Taylor rule".

The structure of the following model can be presented by means of the following system of equations:

$$
\begin{gathered}
\hat{q}_{t}=r+\alpha \hat{Y}_{t-1} \\
\hat{\bar{Y}}_{t}=\sigma \frac{I_{t-1}}{Y_{t-1}} \\
\frac{I_{t}}{Y_{t}}=\varphi_{1} \hat{Y}_{t-1}+\varphi_{2}\left(i_{t-1}-\hat{p}_{t-1}\right) \\
\hat{p}_{t}=\hat{w}_{t}+\hat{e}_{t}-\hat{q}_{t} \\
\hat{w}_{t}=\hat{p}_{t-1}+\hat{q}_{t-1} \\
\hat{X}_{t}=\beta_{j}\left(\hat{p}_{w, t}+\hat{e}_{t}-\hat{p}_{t}\right)+\gamma \hat{Y}_{w, t} \\
\hat{Y}_{t}=\lambda \hat{X}_{t} \\
\hat{e}_{t}=\vartheta\left(i_{t}-i_{t}^{*}-\rho\right) \\
i_{t}^{d}=\left(i_{t}^{*}+\rho\right)+\theta_{1}\left(\hat{p}_{t-1}-\pi_{t}^{*}\right)+\theta_{2}\left(\hat{Y}_{t-1}-\hat{\bar{Y}}_{t-1}\right) \\
i_{t}=\theta_{0} i_{t}^{d}+\left(1-\theta_{0}\right) i_{t-1} \\
\pi_{t}^{*}=\omega \pi_{t-1}^{*}+(1-\omega) \pi_{L P}
\end{gathered}
$$

Where:

q is the growth rate of labor productivity in period $t, \hat{Y}_{t}$ is the growth rate of real output, $\hat{\bar{Y}}_{t}$ is the growth rate of productivity capacity in period $t, I_{t}$ is planed investment in period $t, \hat{p}_{t}$ is the rate of inflation in period $t, \hat{w}_{t}$ is the rate of change in nominal wages in period $t, \hat{e}_{t}$ is the rate of change in nominal exchange rate in period $t, \hat{p}_{w, t}$ is the rate of inflation in the rest of the world in period $t$, $\hat{Y}_{w, t}$ is the rate of growth of world's income in period $t, \hat{X}_{t}$ is the growth rate of exports in period $t$, $\rho$ is the country's risk premium; $i_{t}$ is the nominal interest rate set by the Central Bank in period $t$, $i_{t}^{d}$ is the nominal interest rate target for period $t, \pi_{t}^{*}$ is the target inflation for period $t$ and $\pi_{L P}$ is the long-run target for inflation rate. The constants $r, \alpha, \sigma, \beta, \gamma, \lambda, \theta_{0}, \theta_{1}, \theta_{2}, \varphi_{1}, \omega e \gamma$ are all positive, but $\varphi_{2}, \vartheta$ are negative. 
The equation (1.1) of the system presented above represents the "Kaldor-Verdoorn Law", according to which the growth rate of labor productivity is a positive function of the growth rate of real output due to the existence of static and dynamic economies of scale.

Equation (1.2) presents the growth rate of productive capacity in period $t$ as a function of the rate of investment of period $t-1$. In this setting, the coefficient $\sigma$ must be understood - as in Domar (1946) - as the "social productivity of investment", that is, as a coefficient that determines the increase in productivity capacity or in "potential output" that results from an increase in the level of realized investment expenditures.

Equation (1.3) shows the rate of investment that is desired by entrepreneurs for period $t$ as a function of the growth rate of output in period $t-1$ and real interest rate in period $t-1$. This specification of the investment function combines the so-called "principle of acceleration" (cf. Harrod, 1939) with the Keynesian theory of the "marginal efficiency of capital" (cf. Keynes, 1936, ch.11) according to which desired investment is a negative function of the rate of interest.

Equation (1.4) shows the rate of inflation in period $t$ as being equal to the rate of change in nominal wages plus the rate of change of nominal exchange-rate minus the rate of growth of labor productivity. This equation is deduced from a mark-up pricing rule such as $p=(1+z)\left[\frac{w}{q}+a e\right]$, where: $z$ is the mark-up rate, $a$ is the requirement of imported-raw materials per unit produced, $e$ is the nominal exchange-rate, and $q$ is the average productivity of labor (cf. Taylor, 1989).

Equation (1.5) shows the rate of change of nominal wages as equal to the sum of the rate of inflation in period t-1 and the rate of productivity growth. Labor Unions follow a very simple rule for wage bargains: the rate of change of nominal wages must be high enough to compensate loses of purchasing power due to inflation and to incorporate all productivity gains to real wages.

Equation (1.6) represents the growth rate of exports as a function of the rate of change of real exchange-rate (by definition, equals to rate of change of nominal exchange rate plus the international rate of inflation minus the domestic rate of inflation) and of the rate of growth of world's real income. It must be emphasized that $\gamma$ is the income-elasticity of exports.

Equation (1.7) shows the growth rate of real output as a function of the growth rate of exports. In this setting, coefficient $\lambda$ must be understood as the non-resident autonomous expenditure multiplier.

Equation (1.8) shows the rate of change in nominal exchange-rate as a linear function of the difference between domestic nominal interest rate and the international nominal interest rates adjusted by the country's risk premium. So here it is assumed an economy where prevails a floating exchange rate regime in a context of restricted capital mobility due to the existence of some form of capital controls.

Equations (1.9) and (1.9a) presented the monetary policy rule adopted by the Central Bank. In equation (1.9) it can seen that the nominal interest rate set by the Central Bank in period $t$ has three determinants. The first one is the long-run equilibrium value for nominal interest rate, given by the sum of international interest rate and the risk-premium. The second component is the difference between actual rate of inflation and the target rate of inflation for period $t$. The third and last determinant is the difference between the actual growth rate of real output and the growth rate of productive capacity. In this setting, it is supposed that the Central Bank will change the nominal interest rate relative to its equilibrium value in order to achieve two policy objectives: kept inflation in line with target inflation for that period and to minimize the gap between the actual growth rate of real output and the growth rate of productive capacity.

Equation (1.9a) shows that the Central Bank adjusts slowly the actual value of nominal interest rate to the desired value of this rate, determined by equation (2.9). This equation is a simple formalization of the stylized fact about the behavior of the Central Banks in the operation of 
monetary policy, according to which Central Banks try to avoid sudden changes in nominal interest rates, in order to minimize interest-rate volatility (cf. Barbosa, 2004, p.105).

Finally, equation (1.10) shows that inflation target for period $t$ is a weighted average of the rate of target inflation for period $t-1$ and the long-run inflation target. In this setting it's assumed that Central Bank operates monetary policy in order to produce a gradual convergence of actual inflation to the long-run inflation target, defined in an exogenous way.

It can be shown that the reduced form of the model presented so far is given by the following system of equations:

$$
\begin{gathered}
i_{t}=\left(1-\theta_{0}\right) i_{t-1}+\theta_{0}\left(i_{t}^{*}+\rho\right)+\theta_{0} \theta_{1}\left(\hat{p}_{t-1}-\pi_{t}^{*}\right)+\theta_{0} \theta_{2}\left(\hat{Y}_{t-1}-\hat{\bar{Y}}_{t-1}\right) \\
\pi_{t}^{*}=\omega \pi_{t-1}^{*}+(1-\omega) \pi_{L P} \\
\hat{p}_{t}=\hat{p}_{t-1}-\alpha\left(\hat{Y}_{t-1}-\hat{Y}_{t-2}\right)+\vartheta\left(i_{t}-i_{t}^{*}-\rho\right) \\
\hat{Y}_{t}=\lambda \beta \alpha\left(\hat{Y}_{t-1}-\hat{Y}_{t-2}\right)+\lambda \gamma \hat{Y}_{t, w}+\lambda \beta\left(\hat{p}_{w, t}-\hat{p}_{t-1}\right) \\
\hat{\bar{Y}}_{t}=\sigma\left(\varphi_{1} \hat{Y}_{t-2}+\varphi_{2}\left(i_{t-2}-\hat{p}_{t-2}\right)\right)
\end{gathered}
$$

The steady-state solution for the model presented by equations (2.9b)-(2.13) is such that $\hat{p}_{t}=\hat{p}_{t-1}=\hat{p} ; \hat{Y}_{t}=\hat{Y}_{t-1}=\hat{Y}$ and $\pi_{t}^{*}=\pi_{t-1}^{*}=\pi_{L P}$ (1.14). Getting (1.14) in (1.11) yields the following expression ${ }^{11}$ :

$$
i=i^{*}+\rho
$$

In words: the long-run equilibrium value for nominal interest rate is equal to the sum of the world's nominal interest rate and the risk-premium. In the long-run, nominal rate of interest is independent of monetary policy.

From (1.12) results the following expression:

$$
\hat{Y}=\lambda \gamma \hat{Y}_{w}+\lambda \beta\left(\hat{p}_{w}-\hat{p}\right)
$$

Equation (*) shows the long-run equilibrium value for the growth rate of real output. It's easily seen that long-run growth rate depends on two factors: the growth rate of world's income and the difference between the level of inflation in the rest of the world and the domestic rate of inflation. In this framework, money is not super-neutral, since changes in the rate of inflation (relative to the international level) has a persistent effect over the growth rate of real output. Since the relation between inflation and growth is negative, monetary policy will promote a robust longrun growth if and only if it keep inflation al low levels in comparison to the level prevailing in the rest of the world.

From (2.9b) we get the following expression:

\footnotetext{
${ }^{11}$ In what follows we will suppose that international rate of inflation, the growth rate of world's income and riskpremium are constant in time.
} 


$$
\hat{p}=\pi_{L P}-\left(\frac{\theta_{2}}{\theta_{1}}\right)(\hat{Y}-\hat{\bar{Y}})
$$

Based on $\left({ }^{* *}\right)$, it can be noticed that long-run equilibrium rate of inflation will be equal to long-run target if and only if real output and productive capacity are growing at the same rate.

In order to determine if inflation will converge to its long-run target, it's first necessary to calculate the expression for $(\hat{Y}-\hat{\bar{Y}})$. Getting $\left(^{*}\right)$ in $(1.13)$ yields:

$$
\hat{\bar{Y}}=\sigma \varphi_{1}\left[\lambda \gamma \hat{Y}_{w}+\lambda \beta\left(\hat{p}_{w}-\hat{p}\right)\right]+\sigma \varphi_{2}(i-\hat{p})
$$

Subtracting $(*)$ from $(* * *)$ yields the following expression:

$$
\hat{Y}-\hat{\bar{Y}}=\left(1-\sigma \varphi_{1}\right) \lambda\left[\gamma \hat{Y}_{w}+\beta\left(\hat{p}_{w}-\hat{p}\right)\right]-\sigma \varphi_{2}(i-\hat{p})
$$

Getting (2.2) in (**) yields at:

$$
\begin{gathered}
\hat{p}=\frac{\theta_{1}}{\theta_{1}+\theta_{2}\left[\sigma \varphi_{2}-\left(1-\sigma \varphi_{1}\right) \lambda \beta\right]} \pi_{L P} \\
-\frac{\theta_{1} \theta_{2}}{\theta_{1}\left\{\theta_{1}+\theta_{2}\left[\sigma \varphi_{2}-\left(1-\sigma \varphi_{1}\right) \lambda \beta\right]\right.}\left[\left(1-\sigma \phi_{1}\right) \lambda\left(\gamma \hat{Y}_{w}+\beta \hat{p}_{w}\right)-\sigma \phi_{2}\left(i^{*}+\rho\right)\right]
\end{gathered}
$$

In equation (2.3) can be observed that, in general, long-run equilibrium rate of inflation is different from its long-run target. Convergence will only occur if $\theta_{2}=0$; i.e., the weight of differences between growth rates of real output and productive capacity in the Taylor's rule must be set equal to zero. This result is a natural consequence of the Tinbergen's Economic Policy Theorem, according to which there must be equality between the number of policy goals and the number of policy instruments. Since, in the model at hand, Central Bank has only one instrument of monetary policy - the nominal interest rate - there must be only one goal for monetary policy: to control the rate of inflation.

Considering the fulfillment of the sufficiency condition for convergence of inflation to its long-run target, it's now necessary to turn the attention to the analysis of the behavior of the gap between growth rate of real output and the growth rate of productive capacity. A balanced growth path requires the equality between both rates in order to guarantees a constant rate of capacity utilization in the long-run.

Subtracting (2.1) and (2.2) in (2.3) yields the long-run equilibrium value of the gap between growth rate of real output and the growth rate of productive capacity, which is given by the following expression:

$$
\hat{Y}-\hat{\bar{Y}}=\left(1-\sigma \varphi_{1}\right) \lambda\left[\gamma \hat{Y}_{w}+\beta \hat{p}_{w}\right]-\sigma \varphi_{2}\left(i^{*}+\rho\right)+\left[\sigma \varphi_{2}-\left(1-\sigma \varphi_{1}\right) \lambda \beta\right] \pi_{L P}
$$

The first two terms of the right-hand side of (2.4) are both positives ${ }^{12}$, but the third term is negative, so the long-run equilibrium value of the gap must be positive or negative. However, the gap between the two rates is a function of the value for the long-run inflation target. Central Bank can set the value for the long-run in order to guarantees the equality between the growth rate of real output and the growth rate of productive capacity. In this setting, we can define the Balanced

\footnotetext{
${ }^{12}$ Assuming $1>\sigma \varphi_{1}$.
} 
Growth Rate of Inflation (BGRI) as the inflation rate that guarantees the equality between the growth rate of real output and the growth rate of productive capacity ${ }^{13}$. The BGRI $\left(\pi_{L P}^{*}\right)$ is determined by the following expression:

$$
\pi_{L P}^{*}=\frac{\sigma \varphi_{2}\left(i^{*}+\rho\right)-\left(1-\sigma \varphi_{1}\right) \lambda\left[\gamma \hat{Y}_{w}+\beta \hat{p}_{w}\right]}{\left[\sigma \varphi_{2}-\left(1-\sigma \varphi_{1}\right) \lambda \beta\right]}
$$

In equation (2.5) we can observe BGRI is a function of the international rate of interest, the growth rate of world's income and international rate of inflation. From this reasoning, we can conclude that BGRI have to be set taking in consideration the conditions prevailing in the world economy, or otherwise the long-run target could be set in a level to high or to low for a balanced growth path to exist.

In sum, the analysis of the steady-state solution of the model at hand allowed us to reach the following conclusions:

- There is an inverse relation between the growth rate of real output and the rate of inflation, given the growth rate of world's income and the international rate of inflation.

- The convergence of inflation rate to its long-run target requires that Central Bank has only one goal for monetary policy: to control inflation. This is equivalent to set a weight equal to zero for the gap between the growth rate of real output and the growth rate of productive capacity in the interest rate rule.

- A balanced growth path requires that Central Bank set a long-run target for inflation that is flexible and adjustable to the conditions prevailing in the word's economy. In particular, the long-run inflation target must be increased in periods of increasing levels of international interest rates and/or decreasing growth rates of world's economy.

The institutional arrangement, by setting the way the central banks uses its instruments, gives to the ITR a tight or flexible fashion, as its was shown in Section 2. This "institutional flexibility" is equivalent to the flexibility required by the CB to set its long-run inflation targeting: the tighter the regime is, lesser are the possibilities for the CB to adjust the long-run inflation target to the situation prevailing in the world economy. According to the model developed in this paper, a tighter ITR would make difficult or impossible for the CB to adjust the long-run inflation target when it is required to do so, what would produce (permanent) losses in terms of output growth. The next section looks for empirical evidence to these issues.

\section{Econometric evidence about the relation between ITR institutional design and economic growth}

A wide inspection of the many particular features of monetary policies of ITR countries turns possible to establish the existence of some patterns of institutional ITE formatting and the resulted outcomes for each country. However, the visual inspections of graphs or history analysis just offer some plausible interpretations, without allowing any statistically significant inference. This section of the paper intends to investigate if some institutional features of ITR, in special the

\footnotetext{
${ }^{13}$ This concept has some similarities with the Minimum Unemployment Rate of Inflation developed by Palley (2006). According to him, the existence of a backward bending Phillips curve for low inflation levels guarantees the existence of a rate of inflation that minimizes the rate of unemployment. Central Banks, operating in a context of Inflation Targeting, must then set nominal interest rates in order to achieve this rate of inflation. In our model, the problem is not to achieve the minimum unemployment, but to achieve the highest possible growth rate for real output that is sustainable in the long-run. This requires the equality between the growth rate of real output and the growth rate of productive capacity. The long-run target for inflation must be set in a level such that he differences between both rates is zero.
} 
institutional flexibility of the regime, have any relationship with output growth by estimating panel with data from the countries' experiences. The data was collected from the World Penn Table 6.2 built by Heston and Summers in 2006. The sample consists of 22 countries ${ }^{14}$ time series, and it is restricted to the countries that officially adopt the ITR regime. The sample panel has time series from 1991 to 2004, a period that covers comprehensively the official central banks' adoptions of IT around the world.

The panel analysis estimation has its advantages over the conventional cross-country regressions. In cross-country regressions, it can be estimated only those factor that are tangible enough as to be determined as internationally comparable indicators. However, as underlined in Nelson (1998), intangible effects derived from the countries' social organizations and its institutions - social aspects that are not directly measured - have also its importance in economic growth. Taken into the analysis of the individual effects of the countries, the panel estimations allows the heterogeneity specific effects of the countries that cannot be observable, and whose that one can be reasonably assume to stay constant along the period of the investigation (Peneder, 2004). The use of a dynamic model has the advantage of allowing that the changes in the regimes of ITR, captured by the categorical variables, have its impacts evaluated in the short and in the long run. ${ }^{15}$

In the case of growth model estimation, there are several features that motivated the dynamic panel procedure. It must be outlined first the autocorrelation and persistence in the data, which is high in growth models, requiring a dynamic estimation. Second, the nature of the data suggests that the model is likely to have idiosyncratic differences between countries that are relatively constant through time. Under these circumstances, a solution is the use of conventional instrumental variables and Generalized Method of Moments (GMM) estimators. It is well known that the Arellano-Bond estimator is in most specifications more efficient than other instrument variable estimators, in special in macro panels of the kind studied in this paper (Judson et. al, 1999).

Hence, the growth model is specified dynamically with the introduction of the dependent variables lagged in two periods. However, the direct inclusion of the lagged variables induces a correlation between the stochastic errors and the lagged dependent variable. There are several technical procedures to work with this specification problem: the generalized method of momentums (GMM) of Arellano-Bond (1991) is thoroughly applied in dynamic panel model with short period data. This feature is quite appropriate to the investigation of this paper and used to the panel estimates. The procedure of this method is taking the first-differences from the dynamic model regression equation as a means to remove unobserved time-invariant country-specific effects. Then, the right hand side variables are instrumented in first difference equations using levels of the series, lagged two periods, or more. This procedure has an underlying hypothesis, tough: that is done "under the assumption that time-varying disturbances in the original levels equations are not serially correlated" (Bond et al, 2001).

The regressors can be divided in two groups for explanation of the output growth. The first one explains growth in the spirit of the Kaldorian cumulative causation model presented in the previous section of this paper. On testing the effects of ITR flexibility on growth, the inclusion of these variables control the effects on growth induced by demand-side factors, leaving a ground for monetary policy effects. The second group of variables consists of dummies built to proxy ITR flexibility.

The Table 2 at the end of the text presents the estimates for the aggregate output per capita. The Sargan test is satisfied for all specifications, and so is the test for correlation of second order, being rejected. For all the specifications, it is found that growth variables have its expected signs and are significant.

Ten specifications of the model were estimated; the variables were included one by one along the different equations and combinations. The specifications (I-V) include only the ITR flexibility

\footnotetext{
${ }^{14}$ The selected countries are the following 22 countries that officially adopt ITR: Australia, Chile, Colombia, United Kingdom, Sweden, Spain, Mexico, Czech Republic, South Africa, Thailand, Iceland, Hungary, Norway, Peru, Philippines, Turkey, South Korea, Brazil, Colombia, Poland, Finland, New Zealand.

${ }^{15}$ Although the low frequency of the data (yearly) difficult the evaluation of short-run dynamics on the estimation.
} 
to the panel model, testing the correlation between them and growth. In (V-IX), the demand-side growth variables are added. The several specifications test the econometric consistency of the estimated results. Also, this many equations allow one to identify the importance of a particular variable when a specification is changed.

Within the first group of variables, is tested the relationship between growth and demand-side variables in the spirit of the Kaldorian modified model of the early section. For this intent, as first step, the output growth lagged two periods is included as exogenous variables, $t-1$ e $t-2$. According to the cumulative causation model, the lagged output has a positive impact on the current output due to its positive influence over the labor productivity. In all specifications (I-IX), the lagged output growth is positive and statistically significant. The output growth lagged two periods appears with negative and significant sign in all specifications, with absolute level smaller than the $t-1$; these sign result replicate, therefore, the cyclical cumulative structure of the Kaldorian model (see equation (1.12)).

The growth of investment as a share of output is tested as current and lagged period. The importance of investment expenditures on demand or supply side to the keynesian models is well known and does not need any further comments (in the model presented here, there is a direct relationship with the steady-state output level, as shown on equation (1.2)). In all of the specification where investment growth is included, the results estimated are positive and significant, both to the current and to the lagged variable. The small magnitude of its coefficients, though, as for all the demand-side growth variables, is due to the limited period of the sample and to the difficulty in including more lags, in face of the consequent losses in statistical degrees of freedom, which have negative influence over the statistic stability of the model and its maximum likelihood convergence. In fact, this "problem" is extended to all demand-side growth variables; the intuition underlying these results is that the demand-side magnitude of effects over growth takes a larger time to act; henceforth, more lags were need than the sample allows. On the other hand, the magnitudes of the monetary variables, that have well known faster effects over the output path, appear in the panel results with larger coefficients.

The variable growth of exports+imports as share of the GDP is used here as a proxy of the positive importance of exports share to output growth underlined by the model presented in the previous section before $^{16}$. The signs of this variable alternate in different specifications; the general result is of very small level, although statistically significant. The small frequency of the data and of the lags needed for this variable estimation appears again as the data deficiency to model the demand-side growth.

The growth of exchange rate appears in the results negatively associated to the GDP growth taxes and statistically significant, although in a small magnitude. That is, the results show that the exchange rate appreciation has a negative relationship with GDP growth.

In the specification (V), the categorical variable "IT Adoption" is introduced as a way to test if there is correlation between IT formal adoption and output growth. The results are not statistically significant at a level of $10 \%$. It should be underlined that many attempts of grouping the countries and segregating the sample were accomplished to find a possible significant relationship for this variable. The small sample resulted (many countries adopted ITR only recently) and the inevitable missing values, however, made unfeasible the estimations for those experiences. Hence, according to the results, there is not a significant statistical relationship between ITR and the performance of output growth of the countries. It is important to notice that, as the several countries periods of adoption (and abandonment) of ITR differs, the "IT adoption" variable has many missing values, since in the period that a country has not adopted the ITR, the dummy in consideration is not determined. This happens to the ITR flexibility proxies also.

Is not an easy task to test ITR institutional flexibility: data limitation and few accesses to central bank procedures turn difficult an accurate construction of these variables. Taking that into

\footnotetext{
${ }^{16}$ Unfortunately, the World Penn Tables does not have an export/GDP time-series, which would be a more appropriate proxy to the ends of describing empirically the Kaldorian model.
} 
account, the variables chosen to describe ITR flexibility are: "Core Inflation Target", "Adoption of One Year Horizon" and "Target Losses ${ }^{17 " .}$

Following the established positive relationship between appropriate flexibility of the monetary policies and growth presented in this paper, these proxies are used as a way to characterize, in a approximate way, the ITR flexibility necessary to adapt the economy to adverse exogenous shocks and to preserve the output growth. According to this intuition, that formatting of regimes that allows a larger degree of monetary policies flexibility (but a bounded flexibility under the IT postulates) will have positive outcomes over the path of countries' growth ${ }^{18}$. The intuition behind these proxies that links them to the model in the previous section is as it follows:

i) Central banks that adopt core inflation target are more likely to be less reactive to volatile price shocks and more able to adapt itself to the worlds' current state and its impact over the economy;

ii) A short horizon of converge to the target, as one year, reduces the space for the central bank set its instruments in a flexible way when it is necessary;

iii) "Target Losses" is a (imperfectly) proxy of tight regimes or too ambitious targets that limits the central banks discretionarity to adverse economies' scenarios. As it can be seen, these proxy dummies follows the Kaldorian growth model main intuitions in testing ITR flexibility: a balanced growth path requires that the monetary authorities have institutional space to set a long-run target for inflation that is flexible and adjustable to the conditions prevailing in the word's economy.

The specification (I-IV) includes three categorical variables: "Core IT", "Adoption of one year of time horizon" and "Target Losses" in several combinations. As it was seen extensively in this work, a large space that the central banks have to draw institutionally its IT regime as "tight" or "flexible" can be, in a simple way, summarized in the way that it is chosen the format of these three items.

The variable "Core Inflation" appears with positive and significant sign in all specification it is included. This could possibly mean that de adoption of core inflation targeting is a positive factor for output growth, compared with those countries that use headline inflation indexes. The reason was discussed along this paper: as core inflation is a price index with smaller volatility than the headline inflation, the monetary authorities need not to worry with price movements that are merely temporary. Hence, the policy instrument is called into action only when a real positive trend of price behavior is evident. So, the monetary policy in this scenario reacts with policies that promotes demand contention and has its negative impact over the economic activity lesser than that on countries with headline inflation targeting, ceteris paribus.

The negative and significant sign for the variable "one year horizon" for all the specifications outcomes suggests that such a short term for the target convergence to some countries - tighter regimes, looking for monetary policy consolidation, for example - pays a cost in terms of performance of economic growth.

The variable "Target Losses" also appears with negative sign. A probable explanation for this result is that the target loss is a negative sign for the monetary policy credibility. When there is a target loss, the monetary authorities would need to react with a drastic subsequent correction in interest rates that undermines growth. It's important to notice that a short convergence horizon increase the

\footnotetext{
${ }^{17}$ It is important to underline that the variables "Core Inflation" and "Adoption of One Year Horizon” describes directly the institutional regime flexibility: those countries which adopt core inflation are more likely to react less to impacts of volatile prices; besides, those that adopt the shortest regime of one year for inflation convergence to target constitutes a "tight" monetary policy. Finally, the variable "Target Losses" is an indirect attempt to capture the ITR tightness: one can relate the result of the target loss - possibly being resulted from too ambitious goals or too short periods of convergence from "tight" monetary politics - to the outcomes in terms of output growth of the countries. All the categorical variables were forwarded one period, as an approximate way of capturing the well known lagged monetary effects over the output behavior.

${ }^{18}$ Evidently, a bounded flexibility, under the limits of a monetary regime that is in its origins worried with low inflation rates.
} 
possibility of the central bank not to hit the target; this fact could possibly be one of the channels by which the one year horizon arrangement is a negative factor to economic growth ${ }^{19}$.

\section{Conclusions.}

The ITR dissemination since early 90's and the success of most ITR countries in keeping low inflation rates gave birth to extensive literature, from which one can establish certain consensus in respect to the virtues of the new monetary framework for controlling inflation and credibility building. It was seen in this work that the ITR adoption can be made can be according to many different institutional framework design. The chose made by the central Banks of its ITR institutional arrangements is strongly related to the trade-off between flexibility and credibility faced by the monetary authorities for the time of the adoption of the ITR. This trade-off and its results in ITR institutional arrangements chosen by central banks can lead to "flexible" or "tight" ITRs, depending upon the emphasis that monetary authorities gives, in one hand, to the flexibility virtues of ITR, or in the other hand, the credibility associated to monetary regimes that looks for tough reputation.

This paper intended to evaluate the role of ITR institutional arrangements for the growth performance of ITR countries. The main idea of the paper was to test if the ITR institutional flexibility has any impact over output growth. The results support the hypothesis that the adoption of core inflation indexes, the establishment of a convergence horizon for targeting longer than the minimum (one year), and the ability of central banks in avoiding target losses are positive factors to preserve a strong and sustainable economic growth of ITR countries. As an indirect corollary of these results we can establish that a looser monetary policy has a positive effect over output growth, demonstrating in empirical level the long-run non-neutrality of money, which appears to be the main theoretical proposition of Post-Keynesian economics (CWJMK, Vol. XIII, pp.408-409).

\footnotetext{
${ }^{19}$ Here there is an important comment to be made. The argument of this work is not simply based on the idea that a tighter ITE regime can lead to target losses and, therefore, to the credibility loss of the monetary authority or to the weak output performance. In fact, the recent experience of the inflation targeting in Brazil shows that a tight IT regime can be successful in hitting the targets (since 2004 the Brazilian Central Bank has been had success in hit its announced targets). The argument defended along the paper is that the loss of flexibility in the monetary policy conduction, by designs of a too rigid institutional framework, has direct effects over the long-run output growth, either if the regime is successful in hitting the targets or not. The target losses can obviously have other reasons than the mere rigidity of the monetary policy. The negative sign of the "Target Losses” just arises in the analysis as one more potential harmful vehicle to the output outcomes of the countries, and its signal result could (or could not) be related to the IT regime rigidity.
} 
Table 2 - Econometric Results

\begin{tabular}{|c|c|c|c|c|c|c|c|c|c|}
\hline Real GDP Growth & (I) & (II) & (III) & (IV) & $(\mathrm{V})$ & $(\mathrm{VI})$ & (VII) & (XVIII) & $(\mathrm{IX})$ \\
\hline$t-1$ & $\begin{array}{c}0,651 \\
(7,1 \mathrm{E}-05)^{* * *}\end{array}$ & $\begin{array}{c}0,674 \\
(2,8 \mathrm{E}-05)^{* * *}\end{array}$ & $\begin{array}{c}0,611 \\
(1,1 \mathrm{E}-05)^{* * *}\end{array}$ & $\begin{array}{c}0,600 \\
(0,000)^{* * *}\end{array}$ & $\begin{array}{c}0,414 \\
(0,015)^{* * *}\end{array}$ & $\begin{array}{c}0,418 \\
(0,001)^{* * *}\end{array}$ & $\begin{array}{c}0,455 \\
(0,001)^{* * *}\end{array}$ & $\begin{array}{c}0,438 \\
(0,000)^{* * *}\end{array}$ & $\begin{array}{c}0,429 \\
(0,019)^{* * *}\end{array}$ \\
\hline$t-2$ & $\begin{array}{c}-0,374 \\
(4,5 \mathrm{E}-05)^{* * *}\end{array}$ & $\begin{array}{c}-0,374 \\
(3,0 \mathrm{E}-05)^{* * *}\end{array}$ & $\begin{array}{c}-0,318 \\
(2,9 \mathrm{E}-05)^{* * *}\end{array}$ & $\begin{array}{c}-0,321 \\
(1,5 \mathrm{E}-04)^{* * *}\end{array}$ & $\begin{array}{c}-0,311^{* * *} \\
(0,008)\end{array}$ & $\begin{array}{c}-0,327 \\
(0,000)^{* * *}\end{array}$ & $\begin{array}{c}-0,330 \\
(2,7 \mathrm{E}-04)^{* * *}\end{array}$ & $\begin{array}{c}-0,280 \\
(0,000)^{* * *}\end{array}$ & $\begin{array}{c}-0,299 \\
(0,030)^{* * *}\end{array}$ \\
\hline \multicolumn{10}{|c|}{ Change in Investment Share of GDP } \\
\hline$t$ & $\begin{array}{l}\cdots \\
\cdots\end{array}$ & $\begin{array}{l}\cdots \\
\ldots\end{array}$ & $\begin{array}{l}\cdots \\
\cdots\end{array}$ & $\begin{array}{l}\cdots \\
\cdots\end{array}$ & $\begin{array}{c}0,026 \\
(0,001)^{* * *}\end{array}$ & $\begin{array}{c}0,025 \\
(0,000)^{* * *}\end{array}$ & $\begin{array}{c}0,023 \\
(4,3 \mathrm{E}-05)^{* * *}\end{array}$ & $\begin{array}{c}0,020 \\
(8,16 \mathrm{E}-06)^{* * *}\end{array}$ & $\begin{array}{c}0,019 \\
(0,002)^{* * *}\end{array}$ \\
\hline$t-1$ & $\begin{array}{l}\ldots \\
\ldots\end{array}$ & $\begin{array}{l}\cdots \\
\ldots\end{array}$ & $\begin{array}{l}\ldots \\
\ldots\end{array}$ & $\begin{array}{l}\cdots \\
\ldots\end{array}$ & $\begin{array}{c}0,024 \\
(4,5 \mathrm{E}-04)^{* * *}\end{array}$ & $\begin{array}{c}0,024 \\
(0,000)^{* * *}\end{array}$ & $\begin{array}{c}0,023 \\
(8,8 \mathrm{E}-05)^{* * *}\end{array}$ & $\begin{array}{c}0,016 \\
(3,5 \mathrm{E}-06)^{* * *}\end{array}$ & $\begin{array}{c}0,016 \\
(0,002)^{* * *}\end{array}$ \\
\hline Exports+Imports as GDP share & $\begin{array}{l}\cdots \\
\ldots\end{array}$ & $\begin{array}{l}\cdots \\
\ldots\end{array}$ & $\begin{array}{l}\cdots \\
\ldots\end{array}$ & $\begin{array}{l}\cdots \\
\ldots\end{array}$ & $\begin{array}{c}0,001 \\
(0,022)\end{array}$ & $\begin{array}{c}-0,055 \\
(0,025)^{* * *}\end{array}$ & $\begin{array}{l}-0,008 \\
(0,018)\end{array}$ & $\begin{array}{c}-0,005 \\
(0,002)^{* * *}\end{array}$ & $\begin{array}{c}0,070 \\
(0,033)^{* * *}\end{array}$ \\
\hline Exchange Rate & $\begin{array}{l}\cdots \\
\cdots\end{array}$ & $\begin{array}{l}\cdots \\
\cdots\end{array}$ & $\begin{array}{l}\cdots \\
\cdots\end{array}$ & $\begin{array}{l}\cdots \\
\cdots\end{array}$ & $\begin{array}{l}-1,28 \mathrm{E}-07 \\
(8,48 \mathrm{E}-08)\end{array}$ & $\begin{array}{c}-6,86 \mathrm{E}-07 \\
(5,29 \mathrm{E}-08)^{* * *}\end{array}$ & $\begin{array}{c}-8,1 \mathrm{E}-07 \\
(3,7 \mathrm{E}-08)^{* * *}\end{array}$ & $\begin{array}{c}-8,9 \mathrm{E}-07 \\
(5,15 \mathrm{E}-09)^{* * *}\end{array}$ & $\begin{array}{c}-9,74 \mathrm{E}-07 \\
(7,49 \mathrm{E}-08)^{* * *}\end{array}$ \\
\hline Inflation Targeting & $\begin{array}{l}\ldots \\
\ldots\end{array}$ & $\begin{array}{l}\ldots \\
\ldots\end{array}$ & $\begin{array}{l}\ldots \\
\ldots\end{array}$ & $\begin{array}{l}\ldots \\
\ldots\end{array}$ & $\begin{array}{c}0,010 \\
(0,009)\end{array}$ & $\begin{array}{l}\ldots \\
\ldots\end{array}$ & $\begin{array}{l}\ldots \\
\ldots\end{array}$ & $\begin{array}{l}\ldots \\
\ldots\end{array}$ & $\begin{array}{l}\ldots \\
\ldots\end{array}$ \\
\hline Core Inflation & $\begin{array}{c}0,096 \\
(0,021)^{* * *}\end{array}$ & $\begin{array}{l}\cdots \\
\ldots\end{array}$ & $\begin{array}{l}\ldots \\
\ldots\end{array}$ & $\begin{array}{c}0,087 \\
(1,8 \mathrm{E}-04)^{* * *}\end{array}$ & $\begin{array}{l}\cdots \\
\ldots\end{array}$ & $\begin{array}{c}0,118 \\
(0,002)^{* * *}\end{array}$ & $\begin{array}{l}\ldots \\
\ldots\end{array}$ & $\begin{array}{l}\ldots \\
\ldots\end{array}$ & $\begin{array}{c}0,080 \\
(0,028)^{* * *}\end{array}$ \\
\hline Target Losses & $\begin{array}{l}\ldots \\
\ldots\end{array}$ & $\begin{array}{c}-0,066 \\
(3,0 \mathrm{E}-05)^{* * *}\end{array}$ & $\begin{array}{l}\ldots \\
\ldots\end{array}$ & $\begin{array}{c}-0,081 \\
(1,6 \mathrm{E}-04)^{* * *}\end{array}$ & $\begin{array}{l}\cdots \\
\ldots\end{array}$ & $\begin{array}{l}\ldots \\
\ldots\end{array}$ & $\begin{array}{c}-0,052 \\
(0,002)^{* * *}\end{array}$ & $\begin{array}{l}\ldots \\
\ldots\end{array}$ & $\begin{array}{c}-0,070 \\
(0,016)^{* * *}\end{array}$ \\
\hline Time Horizon & $\begin{array}{l}\cdots \\
\ldots\end{array}$ & $\begin{array}{l}\ldots \\
\ldots\end{array}$ & $\begin{array}{c}-0,508 \\
(0,096)^{* * *}\end{array}$ & $\begin{array}{c}-0,436 \\
(0,053)^{* * *}\end{array}$ & $\begin{array}{l}\cdots \\
\ldots\end{array}$ & $\begin{array}{l}\cdots \\
\ldots\end{array}$ & $\ldots$ & $\begin{array}{c}-0,458 \\
(0,090)^{* * *}\end{array}$ & $\begin{array}{c}-0,293 \\
(0,144)^{* * *}\end{array}$ \\
\hline Constant & $\begin{array}{c}0,006 \\
(1,6 \mathrm{E}-05)^{* * *}\end{array}$ & $\begin{array}{l}\ldots \\
\ldots\end{array}$ & $\begin{array}{c}-0,010 \\
(2,4 \mathrm{E}-05)^{* * * *}\end{array}$ & $\begin{array}{c}-0,006 \\
(1,0 \mathrm{E}-04)^{* * * *}\end{array}$ & $\begin{array}{c}-1,8 \mathrm{E}-04 \\
(0,001)\end{array}$ & $\begin{array}{c}0,002 \\
(0,001)^{* * *}\end{array}$ & $\begin{array}{c}-0,001 \\
(2,7 \mathrm{E}-04)^{* * *}\end{array}$ & $\begin{array}{c}-0,011 \\
(5,1 \mathrm{E}-05)\end{array}$ & $\begin{array}{c}-0,005 \\
(0,002) * * *\end{array}$ \\
\hline Sargan test & $\operatorname{chi} 2(162)=16.91$ & $\operatorname{chi} 2(162)=17.10$ & $\operatorname{chi} 2(162)=19.31$ & $\operatorname{chi} 2(336)=18.91$ & $\operatorname{chi} 2(162)=16.14$ & $\operatorname{chi} 2(162)=10.00$ & $\operatorname{chi} 2(162)=14.71$ & $\operatorname{chi} 2(162)=17.01$ & $\operatorname{chi} 2(336)=17.67$ \\
\hline $\begin{array}{l}\text { Arellano-Bond test that } \\
\text { average autocovariance in } \\
\text { residuals of order } 2 \text { is } 0\end{array}$ & $\begin{array}{c}\mathrm{z}=1.00 \\
\operatorname{Pr}>\mathrm{z}=0.3168\end{array}$ & $\begin{aligned} \mathrm{z} & =1.00 \\
\operatorname{Pr}>\mathrm{z} & =0.3153\end{aligned}$ & $\begin{array}{c}\mathrm{z}=0.99 \\
\operatorname{Pr}>\mathrm{z}=0.3226\end{array}$ & $\begin{aligned} z & =1.00 \\
\operatorname{Pr}>z & =0.3197\end{aligned}$ & $\begin{aligned} z & =1.01 \\
\operatorname{Pr}>z & =0.3147\end{aligned}$ & $\begin{aligned} z & =1.00 \\
\operatorname{Pr}>z & =0.3166\end{aligned}$ & $\begin{aligned} z & =1.00 \\
\operatorname{Pr}>z & =0.3150\end{aligned}$ & $\begin{aligned} z & =0.98 \\
\operatorname{Pr}>z & =0.3249\end{aligned}$ & $\begin{aligned} z & =1.01 \\
\operatorname{Pr}>z & =0.3146\end{aligned}$ \\
\hline Number of Observations & 121 & 121 & 121 & 121 & 121 & 121 & 121 & 121 & 121 \\
\hline Number of Countries & 22 & 22 & 22 & 22 & 22 & 22 & 22 & 22 & 22 \\
\hline
\end{tabular}

significant at the $1 \%, 5 \%$ and $10 \%$ confidence level respectively. The

standard errors are in braces. 


\section{REFERENCES.}

AKERLOF, G., DICKENS, W., \& PERRY, G. (1996). The macroeconomics of low inflation. Brookings Papers on Economic Activity.

ARELLANO, A., \& BOND. (1991). Some Test Specification for Panel Data: Monte Carlo Evidence and an application to employment equations. Review of Economic Studies.

ARESTIS, P; SAWYER, M. (2005). "Aggregate demand, conflict and capacity in the inflationary process”. Cambridge Journal of Economics, Vol. 29.

ARESTIS, P; SAWYER, M. (2006). “Interest Rates and the Real Economy” In: GNOS, C; ROCHON, L.P. (eds.). Post Keynesian Principles of Economic Policy. Edward Elgar: Aldershot.

BARBOSA, F.H. (2004). “A Inércia da Taxa de Juros na Política Monetária”. Ensaios Econômicos $N^{\circ} 534$. Fundação Getulio Vargas: Rio de Janeiro

BERNANKE, B., LAUBACH, T., MISHKIN, F., \& POSEN, A. (1999). Inflation Targeting. New Jersey: Princeton University Press.

BOND, S, A HOEFFLER, E J TEMPLE. “GMM Estimation of Empirical Growth Models.” Economic Paper 2001-W21, 2001.

BOND, S., HOEFFLER, A., \& TEMPLE, J. (2001). GMM Estimation of Empirical Growth Models. Economic Paper 2001-W21.

CARLIN, W., \& SOSKICE, D. (2006). Macroeconomic: Imperfections, Institutions, and Policies. Oxford Press.

CARVALHO, F.C. (1992). Mr. Keynes and the Post Keynesians: principles of macroeconomics for a monetary production economy. Edward Elgar: Aldershot.

COLETTI, D., SELODY, J., \& WILKINS, C. (2006). Another Look at the Inflation-Targeting Horizon. Bank of Canada Review .

DAVIDSON, P. (2002). Financial Markets, Money and the Real World. Edward Elgar: Aldershot.

DOMAR, E. (1946). “Capital Expansion, Rate of Growth and Employment”. Econometrica, vol.14.

FELDSTEIN, M. (1997). Capital income taxes and the benefits of price stability. NBER Workin Paper .

FONTANA, G; PALACIO-VERA, A. (2005). “Are long-run price stability and short-run output stabilization all that monetary policy can aim for?”. Metroeconomica, 58:2.

HEENAN, G., \& PETER, M. S. (2006). Implementing Inflation Targeting: Institutional Arrangements, Target Design, and Communications . IMF Working Paper .

HARROD, R. (1939). “An Essay in Dynamic Theory”. The Economic Journal, vol. 49.

HESTON, A., \& SUMMERS, R. (September, 2006). Peen World Tables Version 6.2. Center for International Comparison of Production, Income and Prices at the University of Pennsylvania .

JUDSON R. A E OWEN A. L (1999) Estimating Dynamic Panel Data Models: A Guide For Macroeconomists Economic Letters, 65: 1.

JUDSON, R., \& ORPHANIDES, A. (1999). Inflation, volatility and Growth. Federal Reserve System, International Finance . 
KALDOR, N. (1988). “The Role of Effective Demand in the Short and Long-Run Growth" In: BARRÉRE, A. (org.). The Foundations of Keynesian Analysis. Macmillan Press: London.

KEYNES, J. M. (1936). The General Theory of Employment, Interest and Money. Macmillan: London.

KEYNES, J.M. (1973). The Collected Writings of John Maynard Keynes. Edited by D. MOGGRIDGE, Macmillan: London. Volumes are referred by CWJMK, followed by the volume number in roman numerals.

KYDLAND, F., \& PRESCOTT, E. (1977). Rules Rather Than Discretion: The Inconsistency of Optimal Plans. Journal of Political Economy .

LEDESMA, M.L. (2002). “Accumulation, Innovation and Catching-up: an extended cumulative growth model”. Cambridge Journal of Economics, Vol. 26, n.2.

LEDESMA, M.L; THIRWALL, A. (2002). “The Endogeinity of the Natural Rate of Growth”. Cambridge Journal of Economics, Vol. 26, N.4.

MADDISON, A. (1991). Historia del Desarollo Capitalista. Ariel, Barcelona.

(2007). Historical Statistics for the World Economy: 1 - 2003 AD. Disponível em: www.ggdc.net. Acesso em: 01/03/2007

MINELLA, A., GOLDFAJN, I., \& MUINHOS, M. (2002). Inflation Targeting in Brazil: Lessons and Challenges. BIS Papers .

MISHKIN, F. (2001). Issues in Inflation Targeting: Price Stability and the Long-Run Target for Monetary Policy. Bank of Canada .

MYRDAL, G. (1957). Economic Theory and Underdeveloped Regions. Duckworth: Londres.

ONO, F.H; JONAS, G.; OREIRO, J.L; PAULA, L.F. (2005). “Conversibilidade da Conta de Capital, Taxa de Juros e Crescimento Econômico: uma avaliação da proposta de plenaconversibilidade do Real”. Revista de Economia Contemporânea, Vol. 09, N.02.

ROBINSON, J. (1962). Essays in the Theory of Economic Growth. Macmillan Press: London.

PALlEY, T. (1996). Post Keynesian Economics: debt, distribution and the macroeconomy. Palgrave: New York.

-- (2006). "Monetary policy in an endogenous money economy" In: ARESTIS, P; SAWYER, M. (Eds). A Handbook of Alternative Monetary Economies. Edward Elgar: Aldershot.

PENEDER, M. (2004). Tracing Empirical Trails of Schumpeterian Development. Papers on Economic and Evolution .

POOLE, W. (1999). Is Inflation too low? Federal Reserve of St. Louis Review .

ROCHA, M; OREIRO, J.L. (2008). “A Experiência Internacional de Regimes de Metas de Inflação: uma análise com painel dinâmico”. : Forthcoming at Nova Economia.

TULADHAR, A. (2005). Governance Structures and Decision-Making Roles in Inflation Targeting Central Ba. IMF Working Paper .

WALSH, C. (1999). Monetary Theory and Policy. MIT Press: Cambridge.

WOODFORD, M. (2003). Interest and Prices: Foundations of a Theory of Monetary Policy. Princeton.

SAYWER, M. (2006). "Inflation Targeting and the Central Bank Independence: we are all Keynesians now! Or are we?”. Journal of Post Keynesian Economics, vol. 28, n.4.

SETTERFIELD, M. (1997). Rapid Growth and Relative Decline. Macmillan Press: London. 
(2005). "Is inflation targeting compatible with post-keynesian economics?”. Downloadable in http://emp.trincoll.edu

SOLOW, R. (1957). “Technical Change and the Aggregate Production Function”. Review of Economics and Statistics, Vol. 39.

TAYLOR, L. (1989). Macroeconomia Estruturalista. Cidade do México: Trillas.

THIRWALL, A. (1997). "Reflections on the Concept of Balance-of-Payments-Constrained Growth Rates”. Journal of Post Keynesian Economics, Vol. 19, N.3.

(2002). The Nature of Economic Growth. Edward Elgar: Aldershot.

VEBLEN, T.B. The Place of Science in Modern Civilization and Other Essays. Huebsch: New York. 